\title{
Multipl Sklerozisin Immünpatogenezi \\ Kısım 2: Hastalığın doğușu ve yükseliși
}

\author{
Immünopathogenenis of Multiple Sclerosis \\ Part 2: The beginning and rise of the disease
}

\author{
Atay Vural ${ }^{1}$, Aslı Tuncer Kurne' ${ }^{1}$, Rana Karabudak ${ }^{1}$
}

Illk kısımda multipl sklerozisli bir hastanın MR görüntülemesinde gördüğümüz bütün plakların aynı anlama gelmediğinden, hastalar arası farklar olduğundan ve konvansiyonel MR görüntülerde göremesek de, kortekste de plaklar olduğundan bahsedilmiști. İkinci kısımda ise, önce hastalığın doğușu ve yükseliși ile ilgili hayvan modellerinin in vivo görüntülemesiyle elde edilmiș veriler sunulacak, sonra da hasta takibinde kullanılan konvansiyonel ve nonkonvansiyonel MR görüntülerinden șimdiye kadar öğrendiklerimiz ve bu görüntüleme yönteminin kısıtlılıklarından bahsedilecektir. Bu bölümün sonunda, multipl sklerozis tedavisinde kullanılmakta olan ve/veya ileride kullanılabilecek ilaçların bazılarının tedavi mekanizmaları hakkında bilgi sahibi olunması ve hasta takibinde birincil rol oynayan MR görüntülerinin daha bilinçli olarak yorumlanır hale gelinmesi hedeflenmektedir.

Anahtar Sözcükler: Multipl Skleroz, Patogenez, İmmünoloji, Deney Modeli, Manyetik Rezonans Görüntüleme In the first part of this review, we described that plaques that we see on MRI are not all the same, there are different plaque patterns between patients and although we cannot detect with conventional MRI, there are cortical plaques in almost all of the patients. In the second part, we will first concentrate on the first phase of disease. We will explain the data that we learned by in vivo imaging of animal models. Thereafter, we will review what we have learned from conventional and non-conventional MRI imaging, and discuss the shortcomings of these methods. After the completion of this section, we hope that readers will have knowledge on the mechanisms of some of the most widely used therapeutic agents and will be able to interpret MR images of MS patients more efficiently.

Key Words: Multiple Sclerosis, Pathogenesis, Immunology, Disease Model, Magnetic Resonance Imaging

\section{Plan:}

\section{Kısım I}

1. Giriş

2. Histopatolojik çalışmalar

2.1. Incelemede kullanilan yöntemler

2.2. Plak çeşitleri

2.3. Aktif plak paternleri

2.3.1 Dört patern hipotezi

2.3.2 Paternlerin evrimi hipotezi

2.3.3 İleri evrelerde plak paternleri

2.4. Gölge plaklar

2.5. Kortikal plaklar

\section{Kısım II}

3. Hastalığın doğuşu: DAE modelinden öğrenilenler

3.1. Modeller

3.2. Illk başta neler oluyor?

3.2.1 Birinci dalga ve immünsurveyans kavramı

3.2.2 İkinci dalga: Lenfosit olimpiyatları ve kemokinler

3.3. İmmün hücrelerin kan-beyin bariyerinden geçişi

3.4. Relaps ve remisyonların üç silahşörü 4. Manyetik rezonans görüntülemenin öğrettikleri

4.1. Konvansiyonel MRG'nin öğrettikleri

4.2. Non-konvansiyonel MRG'nin öğrettikleri

E-posta : atayvural@gmail.com

E-posta : atayvura|@gmal
Tel: 03123051806

Tel: 03123051806

Hacettepe Üniversiesi Nöroloji Anabilim Dalı Sıhhiye, 06100 Ankara 


\section{Hastalığın Doğușu: DAE modelinden öğrenilenler}

\subsection{Modeller}

MS araştırmalarında kullanılan hayvan modellerine deneysel alerjik ensefalit (DAE) modeli adı verilir. İsminden de anlaşılabileceği gibi bu model ilgili deney hayvanına, siklıkla da fare veya sıçanların cilt altına, alerjik yanıt (tip 4/gecikmiş tip hipersensitivite reaksiyonu) oluşturmak amaciyla miyelin yapisinda bulunan proteinlerin yüksek miktarda enjekte edilmesiyle olușturulur. Böylece normalde santral sinir sistemi içerisinde immün sistemden korunmuș olan bu proteinlere karșı, bağıșıklı sisteminde sensitizasyon gelişir. Bunun için seçilen deney hayvanının eksprese ettiği MHC II allelinin, dolayisiyla CD4 T-lenfositlerinin, verilen proteinle sensitize olmaya uygun olması gereklidir. Her insanda MS gelişmediği gibi, her deney hayvanı türünde de DAE gelişmemesinin nedenlerinden birisi budur. Ancak bu da DAE (veya MS) gelișimi için yeterli değildir. Sensitize olmuş CD4 pozitif lenfositlerin lenfoid dokularda miyelin antijeniyle tekrar karşılaşarak aktive olmas1 ve santral tolerans mekanizmalarından da kaçabilmesi gereklidir. Miyelin proteinleri (PLP, MBP, MOG gibi), lenfoid dokularda antijen sunan hücreler tarafindan CD4 + Tlenfositlere sunulur. $\mathrm{Bu}$, bazen antijen sunan hücrelerin (ASH) SSS'den servikal lenf nodlarına migrasyonuyla, bazen de çözünmüş miyelin proteinlerinin lenfoid dokulara ulaşıp ASH'larca işlenmesiyle meydana gelebilir. CD4 + lenfosit aktivasyonunun ardindan bu hücrelerin KBB'yi (kan beyin bariyeri - kan-BOS bariyeri) geçişi gerçekleşir (1). İnflamasyonu takiben SSS'de demiyelinizasyon, aksonal hasar, gliozis gibi MS için tipik bulgular meydana gelir.

Bu model MS hastalığının birebir eșdeğer modeli değildir. Hastalığın bazı özelliklerini yansitmaktan yoksundur. $\mathrm{Bu}$ nedenle değişik proteinler ve değişik genetik temele sahip deney hayvanları kullanılarak ideal modele yaklaşılma çabası sürmektedir. Bununla birlikte en sık kullanılan yöntem olan MOG proteini ile sensitizasyon oluşturulmasina dayanan model sayesinde SSS'nin immünolojik sistemle ilişkisine dair hem MS'te hem de enfeksiyon ve diğer immünolojik hastalıklarda rol oynaması kuvvetle muhtemel çok önemli biyolojik mekanizmalar saptanmıştır. $\mathrm{Bu}$ modelde MOG proteininin subkutan enjeksiyonu sonrası yaklaşık 14. günde özellikle spinal kordda yoğun lökosit infiltrasyonu-plak oluşu$\mathrm{mu} / \mathrm{Gd}$ geçirgenliği/motor semptomlar oluşur. Bu modelde hız kısıtlayıcı basamak periferik lenfoid dokularda sensitizasyonun gerçekleştiği basamaktır. İkinci bir yöntem olan adoptif-transfer modelinde ise aktive $\mathrm{T}$ lenfositleri immünize hayvandan ayrıștırılarak ayrı bir deneğe transfer edilir. Periferik sensitizasyon basamağ1 atlanmış olduğu için bu modelde 3-4 gün sonra hastalık oluşur (2).

Özellikle immün sisteme karşı başka hiçbir organda bulunmayan ayricaliklarla (immune-privilige) korunan SSS'ye bağışıklık hücrelerinin nasıl olup da ve ne yollarla geçebildiği bu modeller ile yapılmış son yıllardaki çalışmalar sayesinde bugün büyük oranda bilinir hale gelmiştir (3). $\mathrm{Bu}$ bilgiler sayesinde hâlihazırda kullanılan tedaviler geliștirilmiş ve nice potansiyel tedavi hedefleri de saptanmıştır.

\section{2. ilk bașta neler oluyor?}

Ransahoffun (4) 2009 y1lında Nature'daki yorum yazısında özetlediği gibi aynı yıl peşpeşe yayınlanan iki araştırma yazısı ile en baştan itibaren periferde sensitize olmuș immün hücrelerin SSS'ye nereden ve nasıl geçtikleri, hedefleriyle (miyelin proteinleri) nasil karşılaştıkları, diğer immün hücreleri SSS'ye nasıl çağırdıkları, çağrılan hücrelerin SSS'ye hangi yolla geçtikleri ayrıntılı olarak gösterilmiştir. İlk aşama "birinci dalga", ikinci aşama ise "ikinci dalga" olarak adlandırılmıştır ve aşağıda bahsedilecektir (4).

\subsubsection{Birinci dalga ve immünsurve- yans kavramı}

Reboldi ve arkadașlarının (5) çalıșması ile "ilk dalga"nın oluşumu detaylarıyla gösterilmiştir. Buna göre periferde sensitize olmuș Th17 hücrelerinin CXCR6 reseptörü ifade eden alttipleri koroid pleksustaki venüllerden stromaya geçerler ve koroid epitelin stromal tarafındaki CXCL20 ligandı ile karşılaştıktan sonra BOS'a geçerek subaraknoid alan boyunca yayılarak beyin ve spinal korddaki tüm perivasküler alanlara ve diğer tüm beyin yüzeyine ulaşma imkânı elde ederler. Buralarda ilgili antijeni (örn. MOG) barındıran antijen-sunan-hücrelerle karșılașırlar ve reaktive olarak karșılaștıkları yerlerde KBB'yi aktifleştirirler ve diğer immün hücreleri SSS'ye çağırırlar. Bu yola CXCR6-CXCL20 ekseni ad1 verilir. Bu bulguya delil olarak CXCR6 geni taşımayan farelerde diğer bütün $\mathrm{T}_{\mathrm{H}} 17$ fonksiyonları normal olmasina rağmen bu hücreler koroid pleksustan BOS'a geçememekte ve neticede DAE oluşmamaktadır. Hatta bu hücreler başka bir yolla aktifleșmiş KBB'ye girebilmelerine rağmen henüz inflamasyon oluşmamış SSS'ye girme yetileri kaybolmuștur. Yabanıl farelerden az sayida $\mathrm{T}_{\mathrm{H}} 17$ hücresi transferi yapıldığında ise bu hayvanlarda da MOG uygulanmasinı takiben DAE'nin oluştuğu gözlenmiştir (5).

İnsanlarda da bu mekanizmanın geçerli olduğuna dair bazı önemli bulgular aynı yazıda sunulmuştur. Örneğin, insanda da koroid epitelyum hücreleri CXCL20 eksprese ederler, ayrıca ilk MS atağında BOS'ta CXCR6 eksprese eden T-hücre sayısı yüksek bulunmuştur. Hasta olmayan bireylerde CXCL20 hemen tamamen koroid pleksus epitelinde bulunurken, MS hastalarında ileri evrelerde astrositler de CXCL20 eksprese etmeye başlarlar (5)?.

Sonuç olarak bu çalışma ile CXCR6CXCL20 ekseninin DAE oluşumunda ve SSS immünsürveyansinda temel rol oynadığ1 gösterilmiştir(5)?.

\subsection{2 İkinci dalga: Lenfosit olimpi- yatları ve kemokinler}

Birkaç ay sonra Bartholomäus ve arkadaşlarının (6) yayınladı̆̆ı çalışma ile de "ikinci dalga" aydınlatılmıştır. Bu çalışma ile ileri düzey mikroskopi teknikleri kullanılarak adoptif-transfer yöntemi ile DAE modeli oluşturulmuş hayvanlarda T-lenfositlerin KBB'yi ge- 
çerek parenkime nasıl ulaştıkları gerçek-zamanlı video kayıtları ile kaydedilmiştir. (6, http://www.nature.com/ nature/journal/v462/n7269/suppinfo/ nature08478.html). Bu videolarda görüldüğü gibi T-hücreleri şekilden şekle girerek ve venüller içinde ve etrafinda adeta akrobatik hareketlerle önce perivasküler alana oradan da parenkime geçmektedirler. T-lenfositleri aktive olmuş KBB'ye ulaştıklarında önce yavaşlarlar, ardından yuvarlanma hareketleri başlar. Kısa bir süre sonra, genellikle kan akımının aksi yönüne doğru, emekleme hareketleri ile lenfositler diapedez için uygun bir yer tararlar. Bulduklarında, çok hızlı bir şekilde transendotel yolla diapedez gerçekleşir ve lümenin öteki tarafindaki gezinme ve tarama aktivitesi başlar. Lenfositler perivasküler alandaki antijen sunan hücrelerle, özellikle de makrofajlarla, tek tek iletişim kurarlar. Bu iletişim görsel olarak iki hücrenin birbirine sarılmasına benzer. Lenfositler bu esnada uygun antijenle karşılaştıkları takdirde ikinci kez uyarılmış olurlar ve de parenkime invaze olarak inflamasyonu başlatırlar. $\mathrm{Bu}$ görüntüler Ransohoff tarafindan güzel bir benzetmeyle "Lenfosit olimpiyatları" olarak isimlendirmiştir (4). Okuyucuların bu etkileyici videoları izlemeleri tavsiye edilir.

İlk dalgada koroid pleksustan BOS'a geçişte kilit rol oynayan CXCR6CXCL20 ekseninden; ikinci dalgada da aktive lenfositlerin KBB'yle karş1liklı etkileşiminden ve bu sayede parenkime geçtiklerinden bahsedilmişti. $\mathrm{Bu}$ ikinci etkileşimin integrinler, kemokinler ve onların reseptörleri sayesinde gerçekleştiği bilinmektedir. DAE modelinde önemli rolü olan kemokinler popüler bir araștırma konusudur ve tedavi potansiyeli açısından önemli bir hedef teşkil etmektedirler. Hâlihazırda klinikte çok önemli bir yeri olan natalizumab bir integrin ( $\alpha 4 \beta 1$ ) antagonistidir. Sağladığı başaryya karşın ciddi yan etkilerinin olması nedeniyle kemokinleri ve reseptörlerini hedef alacak yeni ajanların geliştirilmesi halen önemli bir tedavi potansiyeli taşımaktadır. Kemokin ve reseptörlerinden ön plana çıan üçü CCR4, CCR7 reseptörleri ve endotel hücrelerinde ifade edilen CXCL12 li- gandıdır. CXCL12 sağlıklı bireylerde endotel hücrelerin abluminal yüzeyinde ifade edilen bir kimyasal çekici moleküldür. Abluminal yüzeyde kaldığ1 sürece CXCR4 ifade eden lenfositler damar içinde kalır. DAE gibi hastalık durumlarında ise CXCL12 ifadesi abluminal taraftan luminal tarafa kayarak lenfositler üzerinde bulunan özelikle CXCR4 ve bazen de CXCR7 reseptörleri ile etkileşime müsait hale gelir. Böylece lenfositlerin KBB'ye adezyonu sağlanır ve KBB'yi geçişini sağlayan diğer moleküler mekanizmalar aktive olur. İnsanda da otopsi materyallerinde, MRG ile saptanan demiyelinizan plaklarda beynin diğer kısımlarına oranla lenfositlerde CXCR4, endotelde ve astrositlerde de CXCL12 ifadesinin arttığ1 gösterilmiştir (7). Başka bir çalışmada, CXCR7'nin endotel hücrelerinde de ifade olabildiği, iltihabi durumlarda artış göstererek CXCL12'nin internalizasyonuna ve luminal tarafa geçişinde rol oynadığ1 gösterilmiştir. Deneysel olarak CXCR7 bloke edildiğinde VCAM ifadesi (integrin reseptörü) azalmıştır hastalık aktivitesi de hafiflemiştir (8).

\section{3. İmmün hücrelerin kan-beyin bariyerinden geçiși}

Birinci dalga ile veya aktive T-lenfositler sayesinde aktive olmuş KBB bölgelerinde, integrinler ve kemokinlerin etkisiyle lenfositler önce yavaşlarlar, ardından endotel hücreler üzerinde yuvarlanirlar daha sonra endotel yüzeyde emekleyerek tarama hareketini gerçekleştirirler (6). Uygun bir yer bulunduğunda diapedez iki yoldan birisiyle, ya paraselüler yolla endotel hücreler arasindan ya da trans-endotel yolla hücre içinde oluşan bir kanalla endotel hücrenin direkt içinden gerçekleşir (9). Filopodya adı verilen ayaksı çıııntılarla endotel hücrelerine tutunan lenfositler farklı moleküler aracılar sayesinde iki yoldan birisiyle önce endotel hücrelerin abluminal tarafina ulaşırlar. Elektron mikroskopi (EM) çalışmaları ile hem filopodyalar, hem de endotel hücresi içinde oluşmuş migrasyon kanalı gösterilebilmiştir (10). Bu küçük kanal içerisinden lenfositler sıkışıp uzayarak geçebilmektedir. Burada önce perisit uzantıları, ardından bazal membran yapısındaki açıklıklardan geçerek perivasküler alana geçerler. Konfokal mikroskopi çalışmaları ile de mikrodamarların etrafinı çepeçevre saran bazal membranın yapısında seyrek olarak küçük açıklıkların bulunduğu gösterilmiştir. Lenfositlerin çoğu zaman akım yönünün aksi istikametinde yaptıkları emekleme ve tarama hareketinin, diapedeze uygun bu tarz noktaları bulmak olduğu düşünülmektedir (6).

KBB'nin immün hücrelere karşı bariyer özelliğini yitirdiği kronik evrelerde ise reaktif astrositler bu görevi yerine getirmektedir. Beyindeki yara oluşumu olarak bilinen, her türlü SSS hasarında görülen reaktif gliozisin (veya astrositozis) kronik MS plaklarında özellikle perivasküler alanlarda yoğun olarak görüldügü ve KBB'yi geçerek perivasküler alana ulaşmış inflamatuar hücrelere karşı adeta ikinci bir bariyer görevi gördüğü gösterilmiştir. Genetik olarak gliozisin engellendiği deney hayvanlarında oluşturulmuş EAE modellerinde hastalı̆̆ın belirgin olarak daha ağır seyrettiği tespit edilmiştir (11).

\subsection{Relaps ve remisyonların üç silahșörü}

Hastalığın başlangıcında önemli rol oynayan mekanizmalardan bahsettikten sonra bu noktada devam eden hastalıkta relaps ve remisyonlarla ilişkisi gösterilmiş üç molekülden söz etmek yerinde olacaktır (12). Bu moleküllerden ilki a4 $\beta 1$ integrin molekülüdür. Bu molekül lenfositler üzerinde bulunan bir hücre adezyon molekülüdür. MS ve DAE'de T-lenfostilerin endotele adezyonunda temel rol oynayan molekül olduğu bilinmektedir. Bu moleküle karşı geliştirilmiş bir monoklonal antikorun (natalizumab) MS tedavisindeki başarı bu molekülün ve ligandlarının hedeflenmesinin akılcı bir tedavi hedefi olacăğ$\mathrm{n} 1$ göstermiştir. Bu molekülün endotel yüzeyinde bulunan ligandlarından ilki VCAM'dir (vascular cell adhesion molecule). Daha az bilinen ikinci ligand1 ise osteopontindir. Bu kuvvetli proinflamatuar molekül tıpk1 tümör nekrozis faktör- $\alpha($ TNF- $\alpha)$ gibi ismi nedeniyle MS patogenezi ile ilişkisiz görünse de, MS plaklarında en çok ifade edilen be- 
şinci moleküldür ve endotel dișında pek çok hücrede de üretilir. Endotel yüzeyinde $\alpha 4 \beta 1$ integrin ile etkileşmesi sonucu lenfositlerde nükleer faktör kappa B (NF-xB) yolu aktive olur, Th1, Th2, Th17 lenfosit farklılaşması gerçekleşir ve IFN- $\gamma$, IL-17 gibi proinflamatuar sitokinler salıverilir (13). İkinci ana etkisi ise bu molekül lenfositler içerisinde FOXO3A yolu aracilı̆̆ıyla apoptozu inhibe ederek otoreaktif Tlenfositlerin ömrünü uzatmasıdır. $\mathrm{Bu}$ durumla uyumlu olarak DAE modelinde rekombinan osteopontin verilmesi relapsı başlatır (14). Relaps sırasında verilmesi ise remisyonu engelleyerek hastalığın kronikleşmesine katkıda bulunur. İnsanda osteopontin serum konsantrasyonunun relapslar sirasinda arttığ1 saptanmıştır (15). Tedavide en sık kullanılan ajanlardan biri olan interferon- $\beta$ 'nın dendritik hücreler ve mikroglialar üzerindeki tip 1 IFN reseptörlerine bağlanarak intraselüler osteopontini inhibe ettiği ve böylece IL-17 ekspresyonunu azalttığ1 bulunmuştur (16). $\mathrm{Bu}$ molekülün insanlardaki polimorfizmlerinin hastalığın klinik seyri ile ilişkisi olabileceğini gösteren bulgular da vardır ve RRMS'ten SPMS'e geçişte rolü olabileceği düşünülmektedir (17).

Relaps lehine olan bu iki molekülün aksine $\alpha \beta$ kristalin remisyonda önemli rol oynar. $\alpha \beta$ kristalin bir 1sı şok proteinidir ve MS plağında transkripsiyonu en fazla olan moleküldür (13). Miyelin kilıfta ve astrosit son ayaklarnnda bol miktarda bulunur. $\alpha 4 \beta 1$ integrin ve osteopontin ikilisine stratejik olarak yakın yer alır. Antiinflamatuar etkisi vardır, sitokin sal1nımını azaltıp, lenfosit apoptozunu arttırarak osteopontinin etkilerini geri çevirir. Bunu lenfositler, dendritik hücreler ve astrositlerde $\mathrm{NF}-x \mathrm{~B}$ ve mitojen ile aktive olan protein kinaz (MAPK) yollarını inhibe ederek gerçekleştirir (18). Bu molekülün verilmesi DAE modellerinde remisyonu başlatmaktadır (12). Hem DAE modellerinde hem insanda bu molekülün çok ilginç bir özelliği tespit edilmiştir. MS'in erken evrelerinden itibaren bu koruyucu moleküle karşı hem otoreaktif T-hücrelerince hem antikor üretimi ile yoğun bir saldırı gerçekleştiği saptanmıştır (19). Bu durum hastalı- ğın gardiyanına saldırmasına benzetilmiştir. İnsanda, osteopontine benzer şekilde, $\alpha \beta$ kristalin polimorfizmleri de hastalık seyriyle ilişkili bulunmuştur (20). Hem bu mekanizmanın hem de osteopontinin hedeflenmesi ileride tedavi amaçlı olarak kullanılmaya adaydir.

\section{Manyetik rezonans görüntülemenin öğrettikleri}

Nörologlar olarak ister başlangıç evresinde ister ileri evrede olsun bir MS hastasını değerlendirirken dört MRG serisini takip ederiz: T1, T1-gadolinyum (T1-Gd) ve T2 veya FLAIR. 20 yilı aşkın süredir kullanılan bu tekniklerle ilgili çok sayıda klinik-radyolojik korelasyon ve prognoz tayin etme çalışması yapılmıştır ve ciddi bir bilgi birikimi oluşmuştur. Bugün artık bu serilerin hem hastada gelişmekte olan patolojiyi anlamada hem de uzun dönem prognoz hakkında oldukça kısıtlı bilgi verebildiği bilinmektedir. Örneğin, T2-lezyon yükü ile EDSS arasında yalnız erken evrede geçerli olan zayıf bir ilişki saptanabilmiştir. Gd tutan lezyon yükü de benzer şekilde, relaps hizlariyla korele olmakla birlikte, EDSS ve kalıcı hasar oranı ile zayıf ilişki göstermektedir. Bu iki önemli bulguya "klinik-MR paradoksu" denilmektedir (21). Bu paradoks çok say1da yeni MR tekniklerinin, kontrast maddelerinin ve cihazlarının geliştirilmesine yol açmıştır.

\subsection{Konvansiyonel MRG'nin öğrettikleri}

Konvansiyonel MRG'nin en önemli kısıtlilıkların başında, radyolojik olarak MS plaklarının göstergesi olan T2hiperintensitesinin patoloji hakkında hiçbir bilgi sağlamaması gelmektedir. Temelde T2-hiperintensitesi dokudaki su miktarındaki artışı yansıtır. Ödem, inflamasyon, demiyelinizasyon, akson kayb1, Wallerian dejenerasyon gibi doku olumsuz faktörlerle ilişskili olabileceği gibi; remiyelinize gölge plaklar veya belirgin hasar olmaksızın mikroglia infiltrasyonunu gibi olumlu faktörlerle de ilişkili olabilir (22). MS plaklarının dinamik olduklarından ve remiyelinizasyonun en erken dönemde başlad1ğından bahsedilmişti. Kişiler arası remiyelinizasyon kapasitesindeki farkl1lıklar göz önüne alındığında plak yükü çok fazla görünen pek çok hastanın klinik olarak nasıl iyi seyredebildikleri daha iyi anlaşılır.

Klinikte kontrast madde olarak KBB geçirgenliğindeki artışı gösteren gadolinyum maddesi kullanılmaktadır. Gd akut plakları göstermede etkili bir ajandir. Kontrast tutulumu 3-6 hafta arası sürer, bu nedenle akut plakların önemli bir kısmı MRG ile görüntülenmeden kontrast tutulumları kaybolur (23). T1-Gd, kronik plaklarda da pozitif olabilir. Ayrica KBB'nin bozuk olduğu her durumda Gd tutulumu görülmeyebilir. Progresif evrede kontrast tutulumu olmaksızin aktif inflamasyon ve doku hasarı görülmesi sıktır. T1-Gd pozitif plakların sayısı ve sıklığ1 o hastadaki relaps hızını göstermede etkili olmakla birlikte uzun dönem prognozla yalnızca zayıf bir ilişki gösterir (24).

Uzun dönem prognoza dair bilgiyi T1'deki kara deliklerin sayıs verir (25). Ancak her T1-hipointens alan kara delik değildir. T1'de görülen hipointens lezyonların \%40-80’i aylar içinde remiyelinize olarak izointens hale gelirken, \%20-60'1 kara delik halinde kalıcı olur (22). Büyük, uzun süren, halka-şeklinde kontrast tutan lezyonlardan kara delik gelişme riski daha yüksektir. Ancak bu tip lezyonların bile tama yakın remiyelinize olabildikleri de görülmüştür. Ayrıca hipointensitenin derecesi de önemlidir. Postmortem analiz çalıșmalarında lezyon ne kadar hipointens ise akson miktarının o kadar az olduğu gösterilmiştir (26). Lezyonların hangi paterni göstereceği hastadan hastaya değişmektedir, bazı hastalarda kontrast tutan lezyonlar büyük oranda izointens kalırken diğer bazı hastada plakların çoğu kara deliğge dönüşebilir. Ayrica sekonder progresif evrede de kara delik oluşumu daha sıktır.

T1'den elde edilebilecek bir diğer bilgi serebral atrofinin derecesidir. Serebral atrofinin derecesi nörolojik fonksiyon kaybı ile orta-dereceli ilişkilidir, spinal 
kord atrofisi ise kuvvetli ilişki göstermektedir (27). PPMS'lerde spinal kord atrofisi serebral atrofiden daha belirgindir. Ayrica gri cevher atrofisinin, beyaz cevher atrofisinden daha hızlı ilerlediği de gösterilmiștir. İlginç ve önemli bir bulgu, histopatoloji kısmında da vurgulandığı gibi, serebral kortikal atrofi daha klinik izole sendrom (KİS) evresinde saptanabilmektedir. Dahası en hızlı ilerlediği dönem de bu erken evrelerdir. Yillik atrofi oranları (tüm beyin hacmindeki azalma olarak) KİS'te $\% 0,8$, erken RRMS'te \%0,7, geç RRMS'te \%0,6 olarak bulunmuştur. Atrofinin erken evrelerde dikkat çekmemesinin ve konvansiyonel yöntemlerle saptanamamasının en önemli sebebi erken evrelerde inflamasyon yoğunluğu nedeniyle aynı zamanda dokudaki ödemin de fazla olması ve psödonormalizasyona yol açmasıdır. İleri evrelerde ise hem atrofinin kümülatif olarak artması hem de inflamasyonun geri planda kalması nedeniyle serebral atrofi belirgin hale gelir (27).

\subsection{Non-konvansiyonel MRG'nin öğrettikleri}

Konvansiyonel MRG serilerinin patolojiyi anlamada yetersiz olduklarindan ve klinik-radyoloji paradoksundan bahsetmiştik. Bu paradoksu açıklamaya yönelik olarak, özellikle konvansiyonel tekniklerle normal görünen dokuların, yani normal görünen beyaz cevherin ve korteksin, otopsi çalışmalarında görüldüğü gibi in vivo olarak da patolojik özellikler gösterebileceği hipotezi ortaya atılmıştır. Bu amaçla farklı MR serileri geliştirilmiş, bunlar araştırma amaçlı kullanılmış ve özellikle patofizyolojiye dair çok değerli bilgiler elde edilmiştir. Yakın gelecekte bu yöntemlerden bazilarının rutin klinikte, bazılarının da klinik faz çalş̧malarında kullanıma girmesi kuvvetle muhtemeldir. $\mathrm{Bu}$ bölümde $\mathrm{MS}$ görüntülemesindeki yeni gelişmelerden bahsedilecektir.

NGBC'nin incelenmesinde temel rol oynayan tekniklerden birisi magnetizasyon transfer görüntüleme (MTG) yöntemidir. $\mathrm{Bu}$ yöntemde her voksel için magnetizasyon transfer oranı
(MTR) hesaplanır. Bu oranın azalması akson hasar1 ve demiyelinizasyonu gösterir. Aynı bölgede zamansal olarak artması ise remiyelinizasyonu dolayısıyla gölge plak geliştiğini gösterir. Sonradan plak gelişen bazı alanlarda, kontrast tutulumundan 3 ay önce MTR düşüklüğü görülmüş ve bu değerin progresif olarak azaldığ1 saptanmıştır (28). Beklendiği gibi, T2hiperintens plak alanlarında özellikle de kara deliklerde MTR değeri belirgin olarak düşük bulunur. Ancak NGBC'de de yaygin olarak, daha düşük oranlarda MTR azalması saptanmıştır (29). Bu değişikliklerin KİS döneminde başladığı bulunmuş ve MS gelişimini tahmin etmede rol oynayabileceği öne sürülmüştür. $\mathrm{Bu}$ azalmanın özellikle PPMS ve SPMS hastalarında daha belirgin olduğu tespit edilmiştir (30). Beyaz cevher MTR değişikliklerinin prognoz ile orta dereceli veya kuvvetli korelasyon gösterdiği tespit edilmiştir (31).

$\mathrm{Bu}$ bulgular gelişmiş MR spektroskopi yöntemleriyle de teyit edilmiştir. Tüm beyinden $\mathrm{N}$-asetil-aspartat (NAA) ölçümü yapılmasına izin veren bir yöntem olan H-MRS sayesinde belirgin aksonal hasarın varlığı ve erken evrelerde de görüldüğü gösterilmiştir (32). RRMS hastalarinda NGBC'de NAA/Kreatinin oranının zamansal olarak azalmasının EDSS skoruyla kuvvetli ilişki gösterdiği tespit edilmiştir (33). Hem MTR hem de spektroskopi çalışmalarıyla gösterilmiş olan NGBC hasarının, T2 hiperintens lezyon yüküyle yalnızca zayıf bir ilişki gösterdiği bulunmuştur (34). Bütün bu bulgular beyaz cevher plaklarinın "buz dağının yalnızca görünen kısmı" olduğunu, MS'in tüm beyni tutan yaygın bir hastalık olduğunu göstermektedir. Ayrica, inflamasyondan ve buna bağlı oluşan Wallerian dejenerasyondan bağımsız olarak aksonal hasara yol açan farklı dejeneratif mekanizmaların varlığını desteklemekte$\operatorname{dir}(35)$.

Kortikal plakların prognoza büyük katkısı olmasina rağmen, büyük çoğunluğunun mevcut yöntemlerle görüntülenemediği bu nedenle klinik değerlendirmelerde sıklıkla göz ardı edildiğinden bahsedilmişti. Bu nedenle üç bo- yutlu FLAIR (3B-FLAIR) ve 3B- double inversion recovery (DIR) teknikleri geliştirilmiştir. 3B-FLAIR ile 2BFLAIR'a göre 1,7 kat daha fazla say1da beyaz cevher plağ1 tespit edilebilmektedir (22). 3B-FLAIR'dan yola çıkılarak geliştirilen 3B-DIR tekniğinde, beyaz cevher ve BOS görsel olarak baskılanır, bu sayede kortikal lezyonlar görülebilir hale gelir. Bu yöntem sayesinde FLAIR'a göre beş kat daha fazla kortikal lezyon saptanabilmektedir. 3B-DIR ile yapilan bir çalışmada PPMS hastalarında kortikal plak oranının beyaz cevherdeki plaklara kiyasla daha fazla olduğu gösterilmiştir. MTR ve difüzyon tensör görüntüleme (DTG) çalışmaları da MS hastalarında yaygin kortikal tutulumun erken evrede başladığını ve özellikle SPMS ve PPMS hastalarında daha belirgin olduğunu desteklemektedir (29).

MR tekniklerinin yanı sıra yeni kontrast ve işaretleyici maddeler de geliştirilmektedir. Bu maddelerden en sik kullanılanı UKDOP olarak kısaltılan ultra-küçük demir oksit parçacıklarıdır. Süperparamanyetik özellikteki bu nanopartiküller makrofajların içerisine girerek bu hücrelerin MRG'de görüntülenebilmesine olanak verirler. UKDOP ve Gd verilerek yapılan çalışmalarda hem deney hayvanlarinda hem de insanlarda farklı özellikte plakların var olduğu gösterilmiştir. Bu çalıșmaların bulgularına göre bazı plaklar UKDOP pozitif iken Gd negatif ve/veya T2 izointens olabilirler. Baz1 plaklar ise UKDOP pozitif olduktan birkaç ay sonra Gd pozitifliği gösterebilmektedir. Bu bulgular makrofaj ve lenfositlerin plak oluşmadan çok önce birikmeye başlayabildiğini gösterir (36). Bu bulgular histopatolojik çalışmalardaki bulgularla da korele olmaktadır. Buna göre normal görünen beyaz cevherde yer yer KBB bozulmasina yol açmayan makrofaj ve lenfosit birikimleri oluşmaktadır. Bu odaklardan bazıları plak öncülü olarak davranıp ilerleyen evrelerde Gd pozitif hale gelebilirken, bazıları Gd pozitif plağa hiçbir zaman dönüşmezler (37). Araştırma amaçlı geliştirilen manyetik özellikli antikorlar da bulunmaktadır. Örneğin VCAM antiko- 
runa paramanyetik özellik kazandırılarak yapılan MRG çalışmasında, DAE modellerinde immün hücrelerin $\mathrm{KBB}$ geçişinde anahtar rol oynadığ1 bilinen VCAM molekülünün ekspresyonunun arttı̆̆1 ve zaman zaman lezyon öncesi alanlarda Gd tutulumundan önce görülebildiği gösterilebilmiştir (38).

MS plaklarının klasik olarak immün hücrelerin, KBB'nin aktive olması sonu$\mathrm{cu}$ venlerin etrafinda birikmesiyle oluştuğu düşünülür. Ancak özellikle erken evrelerde MS plaklarının parenkim içerisinde, venlerden uzakta oligodendrosit apoptozu neticesinde oluşan myelin parçacıklarını temizlemek için dokuya invaze olan doğal bağışılklık hücreleriyle oluşabileceğini öne süren görüşten önceki kısımlarda bahsedilmiști. Bu nedenle patogenezle ilişkili olarak merak edilen konulardan biri de MS plakların ne kadarının bir ven etrafinda konumlandığıdır. Bu amaçla yüksek çözünürlüklü MRG ile yapılmış çalışmalar bulunmaktadır $(39,40)$. Üç Tesla'lık MRG ile yapılmış, FLAIR ve SWI kesitlerini üst üste getirerek inceleyen bir çalışmanın bulgularına göre periventriküler lezyonlarin \%91,7'si, periferik beyaz cevher lezyonlarının \%73,1'i, infratentorial lezyonların ise $\% 70,8$ 'i bir veya birden fazla ven etrafinda konumlanmıştır. Aynı çalışmada diğer pek çok hastalıkta da lezyonların benzer oranlarda perivenüler yerleşim gösterdikleri gösterilmiştir. Yani bu özellik MS’e özgü bir özellik olarak görülmemektedir (40). Ven etrafinda yer almayan plakların patogenezinin diğerlerinden farklı olup olmadığı (plak heterogenezi) merak uyandiran bir konudur.

\section{Sonuç}

$\mathrm{Bu}$ makalede multipl sklerozun görünenin çok ötesinde, tüm beyni ve onu saran meninksleri kapsayan, normal görünen beyaz ve gri cevheri bile tutan, karmaşık bir hastalık olduğu anlatılmaya çalışılmıştır. Tedaviyi düzenlerken ve prognozu değerlendirirken T1-Gd ve T2 lezyon yükünden başka önemli parametreler de olduğu akılda tutulmalıdır.

\section{KAYNAKLAR}

1. Goverman J. Autoimmune $\mathrm{T}$ cell responses in the central nervous system. Nat Rev Immunol 2009;9:393-407.

2. Gold R, Linington C, Lassmann H. Understanding pathogenesis and therapy of multiple sclerosis via animal models: 70 years of merits and culprits in experimental autoimmune encephalomyelitis research. Brain 2006;129:1953-1971.

3. Pachter JS, de Vries HE, Fabry Z. The blood-brain barrier and its role in immune privilege in the central nervous system. J Neuropathol Exp Neurol 2003;62:593-604.

4. Ransohoff RM. Immunology: In the beginning. Nature 2009;462:41-42.

5. Reboldi A, Coisne C, Baumjohann D, et al. C-C chemokine receptor 6-regulated entry of TH-17 cells into the CNS through the choroid plexus is required for the initiation of EAE. Nat Immunol 2009;10:514-523.

6. Bartholomaus I, Kawakami N, Odoardi $\mathrm{F}$, et al. Effector T cell interactions with meningeal vascular structures in nascent autoimmune CNS lesions. Nature 2009;462:94-98.

7. Moll NM, Cossoy MB, Fisher E, et al. Imaging correlates of leukocyte accumulation and CXCR4/CXCL12 in multiple sclerosis. Arch Neurol 2009;66:44-53.
8. Cruz-Orengo L, Holman DW, Dorsey D, et al. CXCR7 influences leukocyte entry into the CNS parenchyma by controlling abluminal CXCL12 abundance during autoimmunity. J Exp Med 2011;208:327339.

9. Nourshargh S, Hordijk PL, Sixt M. Breaching multiple barriers: leukocyte motility through venular walls and the interstitium. Nat Rev Mol Cell Biol 2010;11:366-378.

10. Lossinsky AS, Shivers RR. Structural pathways for macromolecular and cellular transport across the blood-brain barrier during inflammatory conditions. Review. Histol Histopathol 2004;19:535-564.

11. Voskuhl RR, Peterson RS, Song B, et al. Reactive astrocytes form scar-like perivascular barriers to leukocytes during adaptive immune inflammation of the CNS. J Neurosci 2009;29:11511-11522.

12. Steinman L. A molecular trio in relapse and remission in multiple sclerosis. Nat Rev Immunol 2009;9:440-447.

13. Chabas D, Baranzini SE, Mitchell D, et al. The influence of the proinflammatory cytokine, osteopontin, on autoimmune demyelinating disease. Science 2001;294:1731-1735.

14. Hur EM, Youssef S, Haws ME, Zhang et al. Osteopontin-induced relapse and progression of autoimmune brain disease through enhanced survival of activated $\mathrm{T}$ cells. Nat Immunol 2007;8:74-83.
15. Vogt MH, Lopatinskaya L, Smits M, et al. Elevated osteopontin levels in active relapsing-remitting multiple sclerosis. Ann Neurol 2003;53:819-822.

16. Shinohara ML, Kim JH, Garcia VA, et al. Engagement of the type I interferon receptor on dendritic cells inhibits $\mathrm{T}$ helper 17 cell development: role of intracellular osteopontin. Immunity 2008;29:68-78.

17. Caillier S, Barcellos LF, Baranzini SE, et al. Osteopontin polymorphisms and disease course in multiple sclerosis. Genes Immun 2003;4:312-315.

18. Ousman SS, Tomooka BH, van Noort $\mathrm{JM}$, et al. Protective and therapeutic role for alphaB-crystallin in autoimmune demyelination. Nature 2007;448:474-479.

19. van Noort JM, van Sechel AC, Bajramovic JJ, et al. The small heat-shock protein alpha B-crystallin as candidate autoantigen in multiple sclerosis. Nature 1995;375:798-801.

20. van Veen T, van Winsen L, Crusius JB, et al. [Alpha] B-crystallin genotype has impact on the multiple sclerosis phenotype. Neurology 2003;61:1245-1249.

21. Brex PA, Ciccarelli O, O'Riordan JI, et al. A longitudinal study of abnormalities on MRI and disability from multiple sclerosis. N Engl J Med 2002;346:158-164. 
22. Poloni G, Minagar A, Haacke EM, et al. Recent developments in imaging of multiple sclerosis. Neurologist 2011;17:185-204.

23. Cotton F, Weiner HL, Jolesz FA, et al. MRI contrast uptake in new lesions in relapsing-remitting MS followed at weekly intervals. Neurology 2003;60:640-646.

24. Kappos L, Moeri D, Radue EW, et al. Predictive value of gadolinium-enhanced magnetic resonance imaging for relapse rate and changes in disability or impairment in multiple sclerosis: a metaanalysis. Gadolinium MRI Meta-analysis Group. Lancet 1999;353:964-969.

25. Truyen L, van Waesberghe JH, van Walderveen MA, et al. Accumulation of hypointense lesions ("black holes") on T1 spin-echo MRI correlates with disease progression in multiple sclerosis. Neurology 1996;47:1469-1476.

26. van Walderveen MA, Kamphorst W, Scheltens P, et al. Histopathologic correlate of hypointense lesions on T1weighted spin-echo MRI in multiple sclerosis. Neurology 1998;50:1282-1288.

27. Fisher E, Rudick RA, Simon JH, et al. Eight-year follow-up study of brain atrophy in patients with MS. Neurology 2002;59:1412-1420.

28. Filippi M, Rocca MA, Martino G, et al. Magnetization transfer changes in the normal appearing white matter precede the appearance of enhancing lesions in patients with multiple sclerosis. Ann Neurol 1998;43:809-814.

29. Cercignani M, Bozzali M, Iannucci G, et al. Magnetisation transfer ratio and mean diffusivity of normal appearing white and grey matter from patients with multiple sclerosis. J Neurol Neurosurg Psychiatry 2001;70:311-317.

30. Tortorella C, Viti B, Bozzali M, et al. A magnetization transfer histogram study of normal-appearing brain tissue in MS. Neurology 2000;54:186-193.

31. Agosta F, Rovaris M, Pagani E, et al Magnetization transfer MRI metrics predict the accumulation of disability 8 years later in patients with multiple sclerosis. Brain 2006;129:2620-2627.

32. Filippi M, Bozzali M, Rovaris M, et al. Evidence for widespread axonal damage at the earliest clinical stage of multiple sclerosis. Brain 2003;126:433-437.

33. De Stefano N, Matthews PM, Fu L, et al. Axonal damage correlates with disability in patients with relapsing-remitting multiple sclerosis. Results of a longitudinal magnetic resonance spectroscopy study. Brain 1998;121 ( Pt 8):1469-1477.

34. Iannucci G, Rovaris M, Giacomotti L, et al. Correlation of multiple sclerosis measures derived from T2-weighted, T1weighted, magnetization transfer, and diffusion tensor MR imaging. AJNR Am J Neuroradiol 2001;22:1462-1467.
35. Filippi M, Rocca MA. MRI evidence for multiple sclerosis as a diffuse disease of the central nervous system. J Neurol 2005;252 Suppl 5:v16-24.

36. Vellinga MM, Oude Engberink RD, Seewann A, et al. Pluriformity of inflammation in multiple sclerosis shown by ultra-small iron oxide particle enhancement. Brain 2008;131:800-807.

37. Filippi M, Rocca MA, Barkhof F, et al. Association between pathological and MRI findings in multiple sclerosis. Lancet Neurol 2012;11:349-360.

38. Serres S, Mardiguian S, Campbell SJ, et al. VCAM-1-targeted magnetic resonance imaging reveals subclinical disease in a mouse model of multiple sclerosis. FASEB J 2011;25:4415-4422.

39. Grabner G, Dal-Bianco A, Schernthaner et al. Analysis of multiple sclerosis lesions using a fusion of 3.0 T FLAIR and 7.0 T SWI phase: FLAIR SWI. J Magn Reson Imaging 2011;33:543-549.

40. Lummel N, Boeckh-Behrens T, Schoepf $\mathrm{V}$, et al. Presence of a central vein within white matter lesions on susceptibility weighted imaging: a specific finding for multiple sclerosis? Neuroradiology 2011:53:311-317. 
